\title{
SUWERENNOŚĆ UKRAINY W LATACH 1917-1921 W KONTEKŚCIE SYTUACJI MIĘDZYNARODOWEJ
}

\author{
SOVEREIGNTY OF UKRAINE IN 1917-1921 \\ IN THE CONTEXT OF INTERNATIONAL SITUATION
}

\begin{abstract}
This article discusses Ukrainian independence war 1917-1921, Polish-Ukrainian relations in this time and Polish-Russian war as a background of building the Ukrainian state. The article relates to international public law. The author explains how and if the West Ukrainian People's Republic reached sovereignty and independence.
\end{abstract}

Key words: Ukraine; Poland; sovereignty; international public law; independence

\section{STRESZCZENIE}

Niniejszy artykuł podejmuje zagadnienie ukraińskiej walki o niepodległość w latach 1917-1921, polsko ukraińskich relacji w tym czasie oraz polsko rosyjskiej wojny jako tła dla budowy ukraińskiej państwowości. Artykuł dotyczy prawa międzynarodowego publicznego. Autor wyjaśnia, jak i czy ZachodnioUkraińska Republika Ludowa uzyskała suwerenność i niepodległość.

Stowa kluczowe: Ukraina; Polska; suwerenność; prawo międzynarodowe publiczne; prawo narodów; samostanowienie

This is an Open Access article distributed under the terms of the Creative Commons Attribution 3.0 PL License (creativecommons.org/licenses/by/3.0/pl/), which permits redistribution, commercial and non-commercial, provided that the article is properly cited. (C) The Author(s) 2014.

Publisher: Institute of Slavic Studies PAS [Wydawca: Instytut Slawistyki PAN] 
$\mathrm{N}$ iepodległościowa działalność ukraińska, rozwijająca się od połowy XIX wieku, przybrała na sile i skonkretyzowała się dopiero w ostatnich latach I wojny światowej. W wieku poprzednim miała formę gtównie nieformalnych spotkań inteligencji (stanowiącej poniżej 2\% ludności ukraińskiej), działalności artystycznej bądź naukowej. Nieliczne ugrupowania polityczne nie odgrywały niemal żadnej roli, czy to na arenie rosyjskiej, czy austro-węgierskiej. W 1908 roku z inicjatywy Ukraińskiej Partii Demokratyczno-Radykalnej utworzono Towarzystwo Ukraińskich Postępowców. Jego centrala mieściła się w Kijowie, a podstawowym celem było ponadpartyjne zwalczanie nacjonalizmu rosyjskiego na etnicznych ziemiach ukraińskich. Nie wyrażano przy tym żadnych planów niepodległościowych, a jedynym postulatem było uzyskanie od Rosji praw równych prawom mniejszości rusińskiej w cesarstwie austro-węgierskim. Do wybuchu I wojny światowej Towarzystwo skupiało się na działalności oświatowej i kulturalnej. Dopiero chylące się ku upadkowi Imperium Rosyjskie stworzyło sytuację sprzyjającą radykalizacji poglądów i dążeń niepodległościowych.

W 1917 roku Towarzystwo Ukraińskich Postępowców wydało odezwę wzywającą Naród Ukraiński do wzmożenia wysitków na rzecz pracy kulturalno-społecznej, mającej na celu otwarcie drogi ku autonomii w rosyjskiej republice federacyjnej. W połowie marca, z inicjatywy T.U.P., utworzono Centralną Rade Ukraińską - kierowniczy ośrodek koordynujący działania różnych środowisk społecznych. Znaczenie rady szybko rosło, przyciągając kolejnych delegatów i zyskując uznanie coraz szerszych grup ludności z całego terytorium historycznej Ukrainy. Jej stosunek do Tymczasowego Rządu w Petersburgu był lojalny i nieuzasadniona wydaje się nieufność rosyjskich kręgów socjalistycznych do rosnącego ruchu autonomicznego.

W dniach 17-21 kwietnia 1917 roku w Kijowie odbył się kongres mający na celu utworzenie organu o szerszym zakresie kompetencji niż Rada. Przewodniczył mu prof. M. Hruszewski - prezes Centralnej Rady. Powzięto decyzję o utworzeniu autonomicznej republiki w ramach Federacji Rosyjskiej, oraz o utrzymaniu stałej liczby 150 delegatów. Przy Radzie powołano Ukraiński Generalny Komitet Wojskowy.

26 maja delegacja Rady przedłożyła Rządowi Tymczasowemu w Petersburgu «Deklarację Ukraińskiej Rady Centralnej», w której zażądano wydania aktów prawnych w sprawie autonomii Ukrainy, ustanowienia przy Rządzie komisarza do spraw ukraińskich oraz wniesiono szereg innych postulatów związanych ze sprawami autonomicznymi. Rząd Tymczasowy uznał się za instytucję niewłaściwą do rozpatrywania deklaracji, odnosząc się do niej z wyraźną niechęcią. Rada Centralna wraz z delegatami Rad Włościańskich, nakłoniona szerokim poparciem społecznym, zdecydowała się działać samodzielnie i wbrew Rządowi Tymczasowemu dążyć do uzyskania autonomii. Na przekór naciskom rosyjskim w Kijowie z pompą zorganizowano II Zjazd Wojskowy.

Niespełna miesiąc później, 23 czerwca 1917 roku, Rada wydała «Pierwszy Uniwersał do Narodu Ukraińskiego», proklamujący poniekąd wolność państwa i wzywający do przygotowania wyborów do Sejmu. Kilka dni później Rada wyłoniła organ wykonawczy w postaci Sekretariatu Generalnego.

Dostrzegając poparcie, jakim została obdarzona Rada, Rząd Tymczasowy w Petersburgu wysłał do niej swoich delegatów. Efektem porozumienia był «Drugi Uniwersał do Narodu Ukraińskiego» oraz zgoda Rządu na utworzenie autonomicznego państwa z wyodrębnioną strukturą wojskową. Decyzja wywołała oburzenie przede wszystkim konstytucyjnych demokratów, którzy w geście protestu ustąpili z rządu. Mimo wszystko, pozwoliło to na utrzymanie niepodległościowych dążeń Ukraińców w ramach jednego z Rosją państwa federacyjnego. 
17 sierpnia Rząd Tymczasowy, mając na uwadze dążenie Rady do osiągnięcia coraz większych kompetencji, wydat «Instrukcję Tymczasową dla Sekretariatu Generalnego Rządu Tymczasowego na Ukrainie». Ograniczono w niej terytorium autonomicznej Ukrainy do pięciu guberni (kijowskiej, wołyńskiej, podolskiej, czernichowskiej i połtawskiej) oraz zmniejszano rolę Sekretariatu Generalnego, przekształcając go z rządu autonomicznego państwa w organ Rządu Tymczasowego. Działania te wzbudziły opór coraz bardziej radykalizującego się społeczeństwa ukraińskiego i doprowadziły do wzrostu antagonizmów.

14 września Rząd Tymczasowy zatwierdził nowy skład Sekretariatu Generalnego, na czele którego staną Wołodymir Wynnyczenko. Kilka dni później rewolucja bolszewicka zlikwidowała ustrój władz petersburskich, powodując ogólny zamęt kompetencyjny. Wobec panującego chaosu i bezsilności nowych władz, Rada znalazła się w dogodnym położeniu do wzmożenia działań autonomicznych. Sekretariat rozszerzył władzę na kolejne gubernie ukraińskie (charkowską, chersońską, jekaterynosławską i taurydzką), ustanawiając jednocześnie nowych komisarzy.

20 listopada został wydany "Trzeci Uniwersał» ogłaszający powstanie Ukraińskiej Republiki Ludowej. W grudniu bolszewicki rząd w Petersburgu starał się doprowadzić do likwidacji Rady, a na skutek niepowodzeń, jednostronnie ogłosił jej rozwiązanie. Doprowadziło to do oczywistej reakcji władz URL i zerwania z pro-federacyjną polityką. 30 grudnia, na zakończenie VII sesji Rady, prof. Hruszewski oznajmił: «Ukraina stała się niepodległą, samodzielną republiką".

W tym samym czasie postanowiono podjąć rokowania pokojowe z państwami centralnymi. Delegacja Ukrainy została formalnie zaproszona w celu prowadzenia pertraktacji do Brześcia. Jej przewodniczący, W. Hołubowicz, złożył wtedy deklarację, że występuje jako przedstawiciel Ukraińskiej Republiki Ludowej rozpoczynającej «od tego momentu swe międzynarodowe istnienie, które utrwaliła przed 250 laty». Delegacja bolszewicka z Trockim na czele, w myśl prawa do samostanowienia, uznała prawa odrębnego poselstwa ukraińskiego. W związku z tym państwa centralne prowadziły rokowania pokojowe z przedstawicielami dwóch odrębnych państw - Ukrainy i Rosji.

24 stycznia 1918 roku został wydany «Czwarty Uniwersał» proklamujący oficjalnie niepodległość Ukraińskiej Republiki Ludowej, wypowiadający jednocześnie wojnę Rosji bolszewickiej i nakreślający plan budowy nowo powstałego państwa. Całkowicie niezależny rząd, pod przewodnictwem Hołubowicza, wysłał do Brześcia kolejną delegację, która ponownie (tym razem $w$ imieniu bytu państwowego niepodlegającego żadnym strukturom federacyjnym) zawarła pokój z państwami centralnymi.

Zawarty 9 lutego traktat oddawał Ukrainie Chełmszczyznę i Podlasie, a jego tajne zapiski obejmowały także podział Galicji.

Po wydarzeniach przełomu lutego i marca, kiedy wojska bolszewickie zajęły Kijów, zmuszając Rade Centralną do ucieczki, zapanował chaos. Armia państw centralnych zdołała, co prawda, odbić stolicę i przekazać ją z powrotem Ukraińcom, jednak powstała sytuacja wyraźnie patowa. Wojsko niemieckie, pod dowództwem marszałka polowego Eychhorna, stało się w rzeczywistości armią okupacyjną. Głośne sprzeciwy Rady doprowadziły do jej rozwiązania, kiedy 28 kwietnia na jej obrady wdarła się grupa żołnierzy, aresztując kilku ministrów. Dzięki zdecydowanemu wsparciu państw centralnych pełnię władzy przejął generał Skoropadski - wydając już 30 kwietnia manifest. Ogłaszał w nim rozwiązanie Rady Centralnej, potwierdzał niepodległość bytu Ukrainy, a także zapowiadał przeprowadzenie wyborów do sejmu. Do manifestu załączono «Ustawę o tymczasowym ustroju państwowym Ukrainy», naznaczającą twór podobny do monarchii konstytucyj- 
nych. Mimo panującego zamętu, rząd Skoropadskiego utrzymywał zdecydowane poparcie państw centralnych, delegując swoich przedstawicieli do stolic państw europejskich. Marionetkowy twór trwał w tym momencie tylko dzięki wsparciu niemieckiemu. Wraz z upadkiem cesarza Wilhelma wpływy Skoropadskiego dramatycznie zmalały. Sam hetman, zarzucając monarchistyczne poglądy, wezwał do natychmiastowego połączenia Państwa Ukraińskiego i Rosji.

W tym też czasie utworzony został Dyrektoriat Ukraińskiej Republiki Ludowej - złożony w znacznej mierze z działaczy Rady Centralnej (Wynnyczenko, Petlura, Szwec). Podjął on działania zmierzające do rozprawienia się z Skoropadskim i jego poplecznikami. Na Naczelnego Dowódcę Sił Zbrojnych został mianowany S. Petlura. Wydał on manifest wzywający «żołnierzy ukraińskich i Kozaków» do walki z samozwańczym hetmanem i wspierającymi go wojskami zaborczymi. Zmęczeni długą tułaczką wojenną żołnierze niemieccy szybko odstąpili od Skoropadskiego i nie wdając się w dalsze starcia, wycofali się. Tymczasem Petlura utworzył blisko 90000 armię opartą na świadomych narodowościowo jednostkach galicyjskich strzelców siczowych, która rozpoczęła powstanie 16 listopada w Białej Cerkwii. Wraz z powszechnym wsparciem mas chłopskich bez większych problemów maszerowała ona na Kijów. Dopiero tam została zatrzymana przez oddziały hetmańskie wsparte przez resztki oddziałów niemieckich. Ostatecznie, po krótkim oblężeniu, Kijów padł 14 grudnia, a Skoropadski zrzekł się władzy.

$\mathrm{Na}$ Dyrektoriacie spoczął trud zapanowania nad chaosem i spełnienia obietnic, dzięki którym zyskał poparcie społeczeństwa. 26 grudnia wydano Deklarację zapewniającą o dalszym dążeniu ku niepodległemu państwu, wzmiankującą kolejne zadania stojące przed władzami, tj. reformę rolną, rozliczenie hetmanatu, reformy polityki społecznej, planowano także zwołanie Kongresu ludności pracującej Ukrainy - jako najważniejszego organu niepodlegtej Ukraińskiej Republiki Ludowej.

W związku z toczącymi się na zachodzie walkami ukraińsko-polskimi, 22 stycznia 1919 roku Dyrektoriat ogłosit kolejny Uniwersał. Ukraińska Rada Narodowa Zachodniej Ukraińskiej Republiki Ludowej «jako rzeczniczka woli wszystkich Ukraińców byłego cesarstwa Austrowęgierskiego i jako ich najwyższy czynnik prawodawczy" proklamował połączenie Zachodniej Ukraińskiej Republiki Ludowej z Naddnieprzańską Republiką Ludową. Podkreślano jednocześnie niepodległy byt zjednoczonego państwa.

Zarówno Deklaracja z 26 grudnia, jak i dalsze działania Dyrektoriatu okazały się zbyt fagodne w oczach bolszewizujących frakcji socjalistycznych, z drugiej jednak strony zbyt radykalne dla znacznej części społeczeństwa. Ponadto w Charkowie coraz aktywniej działał wspierany przez rosyjskich czerwonoarmistów Rząd Rad, jawnie szykując się do walki z Petlurą i URL. Dyrektoriat usiłował uzyskać pomoc państw ententy (popierających Denikina), prowadząc oficjalne rozmowy z przedstawicielami sztabu francuskiego w Odessie. Ostatecznie nie przyniosły one żadnych rezultatów. 4 lutego 1919 roku bolszewicy zajęli Kijów. Wypierając armię Petlury, parli na zachód, dążąc ku połączeniu się z komunistycznymi oddziałami węgierskimi, które niedawno przeprowadziły rewolucję. Błyskawiczne postępy wywołały niepokój na konferencji pokojowej w Paryżu, stanowiąc impuls do wydania zezwolenia Polsce na zajęcie Galicji po Zbrucz.

Przez cały rok 1919 toczyły się walki między Ukraińcami, bolszewikami i Polakami. W międzyczasie Denikin głoszący hasła «Wielkiej Rosji» zajął Kijów i chwilowo wypierając czerwonoarmistów, ogłosit przyłączenie miasta do «Imperium».

21 kwietnia 1920 roku podpisano umowę polsko-ukraińską stanowiącą o polskiej pomocy w uwolnieniu Kijowa i Ukrainy Prawobrzeżnej oraz na mocy której Polska zrzekała 
się roszczeń do Galicji Wschodniej i Zachodniego Wołynia. W umowie tej uznawano explicite niepodległość Ukraińskiej Republiki Ludowej. Ze strony polskiej umowę sygnował kierownik ministerstwa spraw zagranicznych Jan Dąbski, natomiast ze strony ukraińskiej kierownik ministerstwa spraw zagranicznych, przewodniczący delegacji URL na rozmowy z Polską, Andrij Liwicki. Umowy były tajne, jednak w "Monitorze Polskim" opublikowano akt uznania państwowego Ukraińskiej Republiki Ludowej i Dyrektoriatu Symona Petlury jako rządu Ukrainy.

Jednakże przegrana wyprawa kijowska i kolejne klęski doprowadzity do ostatecznego wycofania się oddziałów ukraińskich, a wreszcie ich rozbrojenia. Na większości terytorium Ukrainy utworzono Ukraińską Socjalistyczną Republikę Rad. Był to wyraźny koniec pewnego etapu budowania niepodległego państwa. Stworzono twór o znamionach jedynie teoretycznej niezależności, w którym republikańskie stronnictwa utraciły rację bytu. Ponadto, traktat ryski zawarty w ostatecznej formie 18 marca 1921 roku, potwierdzał istnienie Ukraińskiej Socjalistycznej Republiki Radzieckiej, odrzucając postanowienia umowy z kwietnia 1920 roku. USRR jako tzw. państwo marionetkowe istniało już co prawda od 1918 roku, jednak nie odgrywało w zasadzie żadnej roli, nie posiadając oficjalnie armii, a jedynie słabo rozwiniętą służbę dyplomatyczną. Po 1922 roku stała się jedną z republik związkowych ZSRR. Na arenie międzynarodowej pojawiła się w związku z przystąpieniem do ONZ jako pełnoprawny członek.

Należy wspomnieć również o etnicznych terytoriach Ukrainy w Czechosłowacji oraz Rumuni (szczególnie Besarabia). W Czechosłowacji po okresie dziewiętnastowiecznej intensywnej madziaryzacji pozostała jedynie nieliczna inteligencja tworzona przede wszystkim przez ukraińskich duchownych. Nie była ona jednak w stanie podjąć żadnych działań niepodległościowych. Podobnie wyglądała sytuacja w Rumunii. Pod koniec maja 1919 roku dyplomacja francuska wyraziła zgodę na udział sit rumuńskich w konflikcie polskoukraińskim i przystąpienia do strony polskiej. Casus belli stała się odmowa ZURL udostępnienia linii kolejowej Worochta - Śniatyń. W ciągu kilku dni armia ukraińska została rozbita, a Rumunii rozszerzyli kontrolowane przez siebie tereny.

Podsumowując, w przeciągu lat 1917-1921 podjęto liczne starania utworzenia niepodległego państwa ukraińskiego, oraz podniesienia świadomości narodowej społeczeństwa. Pozwalały one na nagłośnienie kwestii ukraińskiej na szerokiej arenie międzynarodowej. Pomimo to, sprawą sporną pozostaje istnienie, choćby krótkotrwałe, samodzielnego państwa.

W doktrynie prawa międzynarodowego wymieniane są następujące atrybuty podmiotów międzynarodowych: ius tractatuum /ius contrahendil, ius legationis oraz ius standi. Początkowe autonomiczne czy też federacyjne działania Ukraińców w tym aspekcie nie miały żadnego znaczenia. Dopiero utworzenie URL, proklamowanie niepodległości, uznanie przez państwa centralne oraz bolszewików, a ponadto posiadanie przedstawicielstw dyplomatycznych i zawarcie kilku umów międzynarodowych pozwala wysnuć tezę o zaistnieniu podmiotowości prawnomiędzynarodowej.

Zamieszanie okresu hetmanatu i działania niemieckich wojsk okupacyjnych chwilowo pozbawiły URL jakiegokolwiek znaczenia. Jednak po niecałym roku i upadku Skoropadskiego URL została uznana także przez Polskę, między innymi z którą zawarte zostały kolejne umowy, ukształtowało się terytorium oraz utrwaliła władza. Wydaje się, że uzasadniona jest teza, że w tym krótkim okresie od proklamowania niepodległości w styczniu 1918 do czerwca 1920 roku URL posiadała zarówno atrybuty podmiotu prawnomiędzynarodowego jak i państwa. Była tym samym pierwszym w pełni niezależnym bytem ukraińskim na arenie narodów. 
Literatura polska:

Bruski, J. J. (2004). Petlurowcy: Centrum Państwowe Ukraińskiej Republiki Ludowej na wychodźstwie (1919-1924). Kraków: „Arcana”.

Hrycak, J. (2000). Historia Ukrainy 1772-1999: narodziny nowoczesnego narodu. (K. Kotyńska, Tłum.). Lublin: Instytut Europy Środkowo-Wschodniej.

Monitor Polski. (1920, kwiecień 28).

Wasilewski, L. (1925). Ukraińska sprawa narodowa w jej rozwoju historycznym. Warszawa: J. Mortkowicz.

Literatura ukraińska:

Винниченко, В. (1920). Відродження нації: Історія української революції: марець 1917 р. - грудень 1919. Wien.

Кубійович, В. (Red.). (1954-1989). Енциклопедія українознавства. Paris.

\section{BIBLIOGRAPHY}

Literatura polska/Polish literature:

Bruski, J. J. (2004). Petlurowcy: Centrum Państwowe Ukraińskiej Republiki Ludowej na wychodźstwie (1919-1924). Kraków: „Arcana”.

Hrycak, J. (2000). Historia Ukrainy 1772-1999: narodziny nowoczesnego narodu. (K. Kotyńska, Trans.). Lublin: Instytut Europy Środkowo-Wschodniej.

Monitor Polski. (1920, April 28).

Wasilewski, L. (1925). Ukraińska sprawa narodowa w jej rozwoju historycznym. Warszawa: J. Mortkowicz.

Literatura ukraińska/Ukrainian literature:

Kubīovych, V. (Ed.). (1954-1989). Entsyklopediia ukraïnoznavstva. Paris.

Vynnychenko, V. (1920). Vidrodzhennia natsiï: Istoriia ukraïns'koï revoliutsii: marets' 1917 p. - hruden' 1919. Wien. 